\title{
Beauty Magazines' Discourse in the Dystopian World of Louise O'Neill's Only Ever Yours
}

\author{
Ekaterina Muraveva \\ University of Alcalá, Spain
}

Copyright (c) 2018 by Ekaterina Muraveva. This text may be archived and redistributed both in electronic form and in hard copy, provided that the author and journal are properly cited and no fee is charged for access.

\begin{abstract}
This article aims to question media and advertising discourses, exemplified by an issue of Cosmopolitan, from a critical discourse analysis perspective and in a multidisciplinary and interdiscursive manner. Irish novelist Louise O'Neill provides a poignant critique of familiar schemes and patterns through the dystopian setting of her thought-provoking novel Only Ever Yours (2014). She is interested in problematic issues of female identity, various stereotypes related to beauty myths, objectification, female body, commodification, ageism, and other forms of discrimination. The study of her dystopian world cannot be complete without tracing some sociocultural particulars so that the reader can identify the targets deeply rooted in our culture's popular tropes.
\end{abstract}

Key Words. Media Discourse, Advertising Discourse, Beauty Magazine Discourse, Critical Discourse Analysis, Dystopia, Feminism.

Resumen. Este artículo tiene como objetivo cuestionar el discurso de los medios y anuncios, tomando como ejemplo un número de Cosmopolitan, desde una perspectiva de análisis crítico del discurso y de manera multidisciplinar e interdiscursiva. La novelista irlandesa Louise O’Neill ofrece una mordaz crítica hacia los esquemas y modelos familiares a través del marco distópico de su sugerente novela Only Ever Yours (2014). Ella está interesada en cuestiones problemáticas que giran en torno a la identidad femenina, diversos estereotipos relacionados con los mitos de belleza, la objectificación, el cuerpo femenino, la mercantilización, las diferencias por razones de edad y otras formas de discriminación. El estudio de su mundo distópico no se puede completar sin haber localizado diversos rasgos socioculturales de manera que el lector pueda identificar los objetivos profundamente arraigados a las imágenes populares de nuestra cultura.

Palabras clave. discurso mediático, discurso publicitario, lenguaje en las revistas de belleza, análisis crítico del discurso, distopía, feminismo. 


\section{Introduction}

Despite the continuous efforts of women's empowerment movements around the globe to deconstruct and redefine female identities in public domains, there are a great number of discourses that resist this process. They are likely to stigmatize the very term "feminist", and simply continue to reinforce flawed representations of gender roles. On the literary scene, the contemporary feminist dystopia Only Ever Yours (2014), by Irish young adult writer Louise O'Neill, dwells precisely on the problematic questions that our society needs to ask itself before huge posters of idealized and sexualized female bodies. This novel alerts the reader to the dangers of endorsing biologist and essentialist assumptions and of promoting highly asymmetric relationships in media discourse. In the vein of this discussion, it seems appropriate to look at some discourse schemes from the media and advertising and their correlation with the sociocultural constructs questioned by O'Neill's novel. She writes with a feminist agenda that explores utopian (or dystopian?) representations of Woman in modern society and warns about the nightmarish dystopian scenario of male supremacy and complete female subjugation.

This article will employ qualitative literature and linguistics methodological tools to compare and contrast concepts suggested by the novel with some discursive elements of the media. A beauty magazine was chosen as a specific subgenre of the advertising discourse as well as an object of critical discourse analysis (CDA). The discussion is based on an understanding of "discourse" as "a sort of identity kit which comes complete with appropriate costumes and instructions on how to act, talk and often write so as to take a particular social role that others will recognize" (Gee 142). Thus a discourse is of paramount importance in forming identities which can be conveniently transformed through the manipulation of identity markers in the mass media, social media and advertising. For instance, the institutionalized discourse of "glossies" such as Cosmopolitan has long been criticized for encouraging low self-esteem in women, manipulating the female body, reinforcing unattainable beauty standards, conveying dubious ideals of femininity, and ultimately "reaffirm[ing] traditional views of the role of women in society", as Caldas-Coulthard has noted (251). These aspects have been challenged by "second wave" feminist works: Simone de Beauvoir's Second Sex (1949), Betty Friedan's Feminine Mystique (1963), Kate Millet's Sexual Politics (1970) criticized gendered policies, social profiling, and mystification.

Widdowson devised a meaningful metaphor to refer to the monopoly of unwholesome social discourses: "Over recent years, the cynical abuse of language to deceive by doublethink that characterizes the fictional dystopia of Orwell's 1984 has become a reality of everyday life" (8). This comparison made me wonder whether dystopian narratives implicitly address the unsound language patterns and other discursive elements of daily life. If so, the genre of "special interest" magazines, beauty magazines among others, seemed the most appropriate object of study. The majority of pernicious practices around gender have been given more space for discussion in dystopian works over recent years. This has to do with the fact that "utopia and dystopia create new worlds, establish genre, and critique gender roles, traditions, and values" (Wilson 2).

Thus, another important concept for our research - intertextuality - may help to contemplate possible interconnections between the chosen texts. As explained by Plottel, intertextuality facilitates "the recognition of a frame, a context that allows the reader to make sense out of what he or she might otherwise perceive as senseless" (19). In addition, Hutcheon has stated that "interdiscursivity would perhaps be a more accurate term for the collective modes of discourse from which the postmodern parodically draws: literature, the visual arts, history" (130). Therefore, the concept of interdiscursivity will be more helpful in 
interpreting dystopias, as these are expected to contain recognizable targets of attack to enable the reader to perceive critique disguised in fantastical frames.

One relevant example of magazine-novel juxtaposition shows language reminiscent of the beauty consumerism discourse in Only Ever Yours:

PO1 Metallic Silver hair, the computer chanted, \#76 Folly Green Eyes. Muted goldcoloured skin, frosted-pink lips ... (O’Neill 8)

A thin sheath of sea-green silk clings to her perfect body, a one shouldered fulllength toga. 3.0 Brown Black hair is styled in coiled plaits at the crown of her head, \#214 Arsenic Green eyes seared into her luminously pale skin. She's perfect. (O’Neill 19)

These concise labels and even graphic symbols conjure up language schemes of beauty magazines or product advertisements with their perfect, flashy images, though they are refurnished in more sophisticated sequences from a stylistic perspective.

Grounded in the above-mentioned concepts and approaches, this article aims to investigate targets of criticism in dystopia in an interdiscursive fashion and to showcase the genre as a reaction to our culture's discourses and ideologies. To do so, the paper will mostly address patterns and messages of advertisements of different beauty products and fashion items and also take into consideration visual images, textual positioning, interview quotations, and other elements of beauty magazines' media discourse. I shall now proceed to discuss the most influential theoretical and methodological frameworks for the purposes of such research.

\section{Theoretical background}

The 1990s saw the emergence of a new critical approach to describing and explaining texts or, to be more exact, discourses. Thoroughly explored by Fairclough 2013a; van Dijk 1985, 1995; Wodak and Meyer. CDA considers discourses as significant sociocultural practices and, subsequently, "addresses social wrongs in their discursive aspects and possible ways of righting or mitigating them" (Fairclough, Critical Discourse 11). Such objectives stem from the conviction that various forms of public discourse maintain specific examples of community-owned schemata. The latter is not a universal given but a locally constructed "pot of knowledge" that may bear the traces of an ideologically driven social order. Van Dijk emphasizes that ideologies "should be taken as the abstract, 'axiomatic' oasis of the socially shared belief systems of groups" (Handbook 244). Such axioms are highly likely to reveal an imbalance of power relations between the socially dominant group and the dominated. Thus, ideology becomes a powerful informant of discourse, making it a tool of "social power abuse, dominance, and inequality" (van Dijk, Handbook 352). Later, such views inspired an interest in feminist critical discourse analysis, which interrogates language models of gender depiction and political practices of social oppression and control.

A prominent figure in the definition of the concept of ideology was Italian communist philosopher Antonio Gramsci in the 1930s. He linked the term "hegemony" to the process of socialization and considered that such aspects of human life as marriage, family, home, work, traditions, customs, had been naturalized by society to such an extent that its members were unconscious of their hegemonic influence. The individual is trapped between various institutions: schools, universities, the Church, business, political parties, the media, etc. According to French Marxist Louis Althusser, these so-called "ideological state apparatuses" aim to shape our value system by "stuffing every 'citizen' with his daily doses of nationalism, chauvinism, liberalism, moralism, and so on, by means of the press, radio and television" (144). The state-serving intentions of such institutions are criticized in the totalitarian society 
of Only Ever Yours: the omniscient figure of the Father, the state-governed School for "eves", and the presence of socially empowered groups of "Inheritants" who represent the dominant social discourse (symbolically, they are even called Darwin, Isaak, Sigmund, etc.).

A beauty magazine is an artefact of a pervasive mass culture and, as such, is an influential mediator of ideology (Ballaster et al.; Gough-Yates; McCracken; McRobbie). In this respect, Caldas-Coulthard states: "They have a highly important role in the maintenance of cultural values, since they construct an 'ideal' reader who is at the same time both produced and in a sense imprisoned by the text" (250). McCracken further argues that "the woman herself participates in the construction of the idealized images" as she turns the beauty magazine's pages (13). In other words, a woman is compelled to link her everyday realities to semiotic structures strategically placed throughout beauty magazines in the process of constructing her femininity. The latter is controlled by the "state ideological apparatus" of the publisher, the editors, the community, and the society between which she is caught, consciously or subconsciously. As a consequence, "girls and women are typically acculturated to internalize an observer's perspective as a primary view of their physical selves" (Fredrickson and Roberts 173). Furthermore, the female gaze results in the "adoption of a masculine subject position" or "the continuing symmetry of the terms 'woman' and 'commodity' even for women themselves" (Ballaster et al. 38), hence the emergence of theories of objectification and self-objectification.

Due to their stylistic and structural differences, the juxtaposition of novels and magazines is relatively uncommon. Cook, for example, sets apart literary and advertising discourse by stating that the schemata these texts evoke are of a different nature: adverts are unquestioned and predictable, while literary pieces are more dynamic and less consumeroriented. He suggests that in adverts scripts only exist for their own sake and not to "illuminate goals and plans" (Theory 150) of the characters. This leads to a hypothetical question: If the characters presented in the media and advertising discourse (highly idealized models, subordinated women, sexually emancipated women, under-represented ethnic groups, etc.) were to inhabit an actual world and had goals and plans according to their scripts, what would it look like? In my humble opinion, Only Ever Yours provides a comprehensive illustration of such a world. To exemplify their interplay: advertisers use direct address in the form of imperatives to reproduce a relatable friendly interaction ("Get what you really want. Slim - Fast!" (137), "Look hot tonight" (90), "Work what you got" (111)); and Only Ever Yours' main character, freida (O'Neill presents character names in lower case), relives these mantras through her internal monologue ("I am skinny" (103), "At least I am thin" (122), "I am pretty. I am a good girl. I always do as I am told" (11)). The repetition of these utterances sounds like a chorus of female voices following the commands of the oppressing discourse.

Curiously enough, fictional genre and magazine discourse have explicitly collaborated in the past. In Victorian England, around the 1860s, popular sensational novels on crime and the domestic lives of the middle class were serialized and featured in the emerging genre of family magazines. The editors deliberately placed relevant articles in the same pages, and the authors drew inspiration from magazines' reports on crimes, scandals, and other social troubles. This exemplifies "a different level of intertextuality within the periodical discourse of the 1860s, when magazines and serial novels converged in dramatic ways, offering readers textual juxtapositions which stimulated new reading practices" (Wynne 19). This is not to say that O'Neil resorts to the same practice but to suggest that her work aligns with the policies of her time so vividly due to the abundant knowledge of the discourse in question, fuelling her protest against its manifestations.

Both literature and discourse should be open to interdisciplinary approaches permitting a closer interaction between texts and the social context, and "the study of "reception"" of literary works, "mostly from an intuitive socio-historical point of view" (van Dijk, 
"Introduction" 6). These ideas undergo further development in psychonarratology. Thoroughly discussed for the first time by Bortolussi and Dixon, this methodological tool provides a certain insight into the psycho-cognitive reading experience that has become a vital part of the communication between the text, the reader, and the context in which both operate, if not of a narrative itself. Bortolussi and Dixon came to the conclusion that the content of a narrative or discourse is properly processed once readers can refer to the story behind the text through references presented within it (17). In discourse, groups of such references are shaped into language and text schemata and world schemata (see Cook, Discourse).

More recently, Stockwell contemplates schema theory as a point of departure for literary analysis or, in part, narratological analysis. He pinpoints three fields that account for textual structures: world schemes, text schemes, and language schemes (80). This distinction makes a case for my analysis of a dystopian narrative, where text schemes and language schemes may shape the world in unfamiliar (or familiar?) ways by virtue of the literary genre. It is a stylistic goal of literature to defamiliarize, or, as Stockwell suggests, "refamiliarise" the expected patterns to have an impact on the reader. The aforementioned concepts open possibilities for a search for "constitutive schema" that form in a literary context due to "the reading angle that 're-registers' the original schema and processes it in terms of literary factors" (Stockwell 80). First mentioned by Bartlett as a "setting" for inferring meanings from the given patterns ("effort after meaning") (20) and later emerging as a major aspect of artificial intelligence, schema theory proliferated in the 1980s as an approach to literary textual analysis - it was applied to narrative analysis by Freundlieb (1982) and to poetry analysis by Semino. The latter has pointed out that "comprehension crucially depends on the availability and activation of relevant prior knowledge" (81), pieces of which the writer and the readers are likely to share. Following this research, and the important conceptual frameworks of Cook (Discourse), Fairclough (Critical Discourse), van Dijk (Handbook), and Wodak and Meyer, this article attempts to approach dystopian fiction as a schematic reality. Although dystopias present alternative worlds, they draw on the schemes of the utopian genre in complete contradiction to the original and use scripts available in the socially constructed and ideologically controlled discourse. Dystopia's interaction with reality is more tangible than in other literary genres, since "it is usually clear that the real referents of dystopian fictions are generally quite concrete and near-at-hand" (Booker 19).

\section{Materials}

Only Ever Yours is set in a post-apocalyptic world where females are specially grown as "eves" who are then redistributed into clear biological groupings: "companions", "concubines", and "chastities", defining their future relations to men. The girls are taught certain values in schools, or simply brainwashed. It is my conviction that beauty magazines bear a responsibility for similarly dubious educational purposes.

Cosmopolitan is the largest, highest-selling magazine the world over and presents itself as "a bible for fun, fearless females" aged 19 to $34 .{ }^{1}$ It is thus conscious of its position as a reference point for young women and touches upon female identity issues. The alliteration used as a rhetorical device in the magazine's slogan emphasizes the expectations placed upon a woman to be fun and fearless. This idea is indicative of a rather biological approach focalizing sexual belonging. Moreover, there is an assumption that gender construction is grounded in the conventional perspective of woman in essentialist terms and the negation of actual experience. The publisher's philosophy sets up an obvious distinction between different types of women and between men and women in a way that is similar to the Only Ever Yours' categories of "eves" and "eves" vs "Inheritants". This labelling technique is essentially the foundation of Only Ever Yours' world. 
O'Neill must have taken inspiration from the beauty industry itself, since she is known to have worked at another magazine for young women - Elle - in New York City, and she has stated that "every single thing" in Only Ever Yours "was inspired by a real-life event". ${ }^{2}$ While the present article is not interested in tracing all those real-life events, it is going to explore some debate-generating patterns of our day-to-day lives. In this particular case study, close attention will be paid to the Cosmopolitan issue of September $2013^{3}$ - approximately contemporaneous to the writing of the novel (apart from this, the choice bears no ideological implications and is random).

\section{Recurrent schemes and frames in beauty magazine discourse}

Grounded in the methods of CDA, I shall delineate the most distinctive textual and extratextual features of beauty magazine discourse below, providing some examples from the Cosmopolitan issue of September 2013, and open up a discussion of their ideological implications. Stockwell's study of schema theory will be used to engage more closely with dystopia as a discourse and as "social criticism" (Booker).

\section{Visual images and text format}

Beauty magazines combine various modes of communication, hence the abundance of visual images and different variations of written text (upper-case, letters in bold, graphic symbols, text fonts, etc.). For instance, the Cosmopolitan cover projects an all-mighty female image of young American actress Nina Dobrev, a role model for more than 14 million followers, according to her Instagram profile. ${ }^{4}$ Her unnatural posture highlights every part of her body. Notably, her image visually intercepts the text delineating the issue's themes, and every single element of her is somehow manipulated to play into the text. The affective compound adjective "mind-blowing" is strategically placed near her loose, streaming wind-blown hair, giving cohesion to the text-image scheme. This highly sexualized entity is presumably intended as a representation of desirable femininity. McCracken defines covers as "windows to the future self" and "selective frames that color both our perceptions of ideal femininity and what is to follow in the magazines" (14).

Another skewed pattern is encoded in the term "awesome arm workout", linked to Dobrev's arm by an arrow, essentially subjecting a female body to an anatomical analysis. The lexical item "awesome" is attitudinal and positively coloured. Here the adjective "awesome" defines and describes the noun "workout", though another noun, "arm", is placed before it as a modifier. The editor, however, manipulates this grammatical pattern by highlighting the grammatically non-dependent construction "awesome arm" in yellow. This device suggests that there is a way to measure a person's worth by means of objectification and evaluative assumptions about their body routines. In addition, the advertiser may even provide actual evaluations as in "Hair a 10" (63), the number alone being mentioned six times on the same page to conjure up the transcript of records' scheme.

In general, visuals only help reinforce the schemes of desirable beauty standards, leaving room for CDA to question the repercussions of such mental models. One of these may be summarized as "social inequality as it is expressed, constituted, legitimized, and so on, by language use (or in discourse)" (Wodak and Meyer 10).

\section{Lexical choices}

Reah affirms that "a simple and obvious way in which language can be used to present specific ideas about a group is through the choice of words used to name and describe that 
group" (55). As an example, the discourse of beauty magazines sets out to create a perfect one-dimensional utopian world inhabited by beautiful, young, and free individuals. For this purpose, it deploys many repetitions, synonyms, terms with positive connotations ("powerful", "strong", "badass", etc.). The celebratory discourse of contemporary beauty magazines exploits feminist agendas and foregrounds ideas of freedom and emancipation (e.g. "Strong, Single \& a Badass Heartbreaker").

Comparative forms of positively coloured adjectives are also a favourite linguistic tool of advertisers. "Skin smoother ... and stronger. Looks younger ... more translucent", "Wake up to more beautiful skin - every day" (4). These appear to lack a referential source and simply underline the necessity of flaw-eradication.

The lexical corpus referring to the technological and scientific advances of the century - "advanced repair", "a major innovation", "breakthrough serum", "powerful new formula", "exclusive technology" - are almost interchangeable. Synonyms bring into view processes of modification or improvement deemed necessary by default.

\section{Rhetorical devices}

Metaphor, hyperbole, metonymy, and other rhetorical devices ensure that the conventional schemes of female body perception are observed. Even the skin - an intrinsic part of the human body - gains an agency of its own by means of a metonymic device through "THE STORY BEHIND JENNIFER'S SKIN". Human body parts possessing a voice extrapolates the idea of objectification into the subjectification of an object. This tendency is as typical of the advertising discourse as one of dehumanization.

The question "What if a foundation could TRANSFORM YOUR SKIN IN 4 WEEKS?" (8) implies a literal transformation with "super-blendable make-up". This hyperbolic device promises women an enhanced look. Such hopeful promises permeate all advertising discourse.

\section{"Mythical groups of reference" (Edelman, qtd. in Menz 236)}

I have pinpointed above the non-existent referents of the comparative adjectives. Another important device in overall media discourse has to do with the quoting of non-credible sources, as in, "Lack of sleep. Is it aging your skin too fast? New research says - it is" (4). Presented with the general question that requires only a yes/no answer, the female audience is asked to trust supposedly authoritative "research".

\section{Syntactic parallelisms}

In the top right corner of the Cosmopolitan cover, beside the model's head, there is a caption that displays a necessary mind set: "WHAT GUYS THINK of the PICS YOU POST". This syntactic parallelism aims to create a very clear cause-and-effect relation between the two events: girls post pics and, as a result, guys form their opinions. Another example sets a propositional scheme for female behaviour in the purchase of mascara: "you blink, they won't miss it".

\section{Presuppositions and implicatures}

These more complex structures justify certain world schemes. For example, another implicit promise - "INSTANT PERFECTION ANTI-AGING MIRACLE" (118) - demonstrates a working presupposition: ageing is never a good thing. Hence women who experience it 
should feel threatened by their own bodily or psychological changes. The advert also implies the need for remodelling to rectify the problem.

\section{Propositions}

The examples above demonstrate that the editors create mental frames based on constant oppositions between young and old, slim and obese, women and men, right and wrong, the norm and stigma, etc. This biased proposition is rather eagerly employed in racist, sexist, and ageist discourses among others. Such deliberate polarization is one the most persistent practices in constructing ideological schemata about the external reality.

Now that I have discussed briefly some of the unsound patterns of beauty magazines, I shall proceed to show the interdiscursive differences and similarities between the schematic portrayals of women in Only Ever Yours and the Cosmopolitan issue. This analysis will be organized into themes that contain the most burning issues in dystopias and young adult feminist dystopias, in particular.

\section{Analysis of materials}

\section{"Standards must be upheld" (58)}

According to Vukadinovic, who explored traditional roles of women in literature, "some female characters stand as representatives of a highly idealized perception of womanhood. Others are traditionally perceived as representatives of womankind in its manipulative and most inferior form" (4). Both groups are purposefully brought into focus in Only Ever Yours through the "companions" and "concubines". Both an ideal and an anti-ideal are necessary for compliance with the dictates of their society which needs standards to compartmentalize women in their places. The most valuable standard, and even the moral compass, is beauty. The novel's cover, depicting a Barbie doll, instantly evokes schemes of consumption, objectification, artificiality. Thanks to the newest technological advances of post-apocalyptic science "eves" are designed to be perfectly beautiful. While at school, every morning they are subjected to a series of procedures that involve make-up and dress-up. These are inspired by fashion shows broadcast in the school facilities, and social networks, and aim to make them look like cover girls. It is no coincidence that the very phrase "cover girl" is a culturally accepted idiom in the English language that means that a girl is glamorous and pretty enough to be featured on the cover. The Cosmopolitan cover has fully embraced the beauty standards and looks like the type of picture the novel's female characters would want to post of themselves in order to get as many "likes" from their potential husbands - the "Inheritants" as possible. This would strengthen their chances of being chosen as "companions" powerless ornamental life partners in a suffocating phallocentric universe. It is noteworthy how informed O'Neill's critique is when it comes to jotting down a series of instructions for "eves":

1. Turn partially to the camera, one foot in front of the other

2. Weight on the back foot

3. Left hand on hip

4. Dazzling smile

I hope the foto was perfect. (O’Neill 13)

O'Neill poignantly envisages the girls' struggles in the world surrounded by myriad constant visualizations of a "beauty myth". In a thought-provoking manner, they almost coincide with 
the feats the Cosmopolitan cover model performs. Her photoshopped body is contrived as a symmetrical, smooth-skinned, thin, perfect entity. The pose, devoid of any real intention (as seems to be the case in the eves' school), presents her body as an "ornamented surface", in Sandra Bartky's terms (60).

In general, looks play a central role in both universes. O'Neill describes the "eves" using mobile applications to construct their looks in order to elicit an audience response: they will be evaluated, "liked", and ranked afterwards. Is she channelling social media or magazine discourses that in a similar vein succeed in launching galleries of mannequins? As a friend's professor commented, humanity still spends more money on cosmetics than scientific research (personal communication 2016). Like freida and the other girls, many women in O'Neill's world dedicate themselves to performing certain rituals to evaluate their beauty and success, while competing for the best "Inheritant". In fact, on the subject of rituals, "adverts and commercials now offer the same kinds of promise and hope which religions and social philosophies once held as their exclusive rights" (Ikaria-Maina 1563). Similarly, the school of "eves" offers ideological promises of a better life and the government's version of "common sense". Here women do not need to purchase anything: they are made in the desired image and are conditioned to maintain it.

Being emotionally fluid and fearful contradicts the normative behaviour in both universes. The existence of sad, unhappy women is anathema to beauty magazines - only the "fun and fearless" are welcome, according to Cosmopolitan's slogan. In this vein, the narrator of Only Ever Yours is constantly aware of the fact that girls should smile, seek approval, be good and complacent, just like children, which is one of the postulates of androcentrism. There is no context where they can cry, look bad or sad. Their goal is to contain themselves: "I am a good girl. I am appealing to others. I am always happy and easy-going" (76). This seems to bear an implicit satiric intent, since such emotional reserve is being portrayed in a biased man-pleasing manner, and women are to follow the scripted social roles (the "companion" is a nice feminine creature; the "concubine" a strong, sexually appealing femme fatale; the "chastity" a strong, unappealing "iron lady". Even in the twenty-first century these symbolic structures have taken up residence in woman-oriented discourse. O'Neill uses multiple propositions of binaries that permeate her alternate universe (thin vs fat, appealing vs non-appealing, happy vs sad, perfect vs imperfect). One is always favoured over the other. All these points represent "ideological squares" (see van Dijk "Discourse") and a positive vs negative and "us" vs "them" philosophy, making it hard for women to fit in a socially approved category.

Measuring up to the standards of beauty, youth, and charisma seems like an impossible task. Potential female viewers or customers inevitably lack some of these qualities, hence the infinite quest to become more beautiful every day.

Comparison precedes compliance with the standard. Freida and the other girls compare everyone to everyone else as part of their daily routine: "I'll wake up and be paler, thinner, different. Better ... I have far to go because I need to get better and better" $(11,267)$. Constantly comparing herself to other eves - megan, the leader of the ranking, and even her only friend isabel - freida drastically devalues herself. Consequently, she wishes she were someone else, rejecting her whole being. Freida's internal monologue - "I wish I looked like you. Everything would be easier if I looked like you" (8) - might remind one of young girls seeking ways to look more like fashion models or Hollywood actresses and presents a conclusion that the magazines want them to reach. Several decades ago, according to McRobbie, "the whole field of magazines shifted towards seeking improvements for the individual" and formulated the premises of "commercial femininity" (191).

To further my argument, I cite the following utterance from Cosmopolitan cover girl Dobrev: "I can take a lot of pressure. I am constantly trying to make myself better" (208). 
This quote comes from the interview with the cover star and is supplemented by photos of her posing in designer clothes. Resembling a post-feminist discourse, it asserts a fraudulent symbolism of femininity. In this particular case, Nina Dobrev is summoned to signify a world of goodness and success and this is demonstrated by a picture of her modelling pretty clothes with confidence. How does her actual story relate to the photographs, which bear no logical implications about her real-life experiences such as her gymnastic background, college, work pressure, yoga? Looking at this piece from "a multimodal cohesion framework" (Bateman 161), the text-image relationship fails due to incoherence and manipulation. While the actress was actually talking about her constant desire to learn more and work twice as hard, as she never finished college and had to prove herself on many occasions (211), the pictures and the quotations seem to conjure up the biased idea that bettering oneself is directly linked to photoshopped images.

Another implication is suggested by the term "match", which frequently resurfaces in magazine discourse, as it attempts to convince women that the possibility of matching every ideal as a result of self-improvement rituals is achievable.

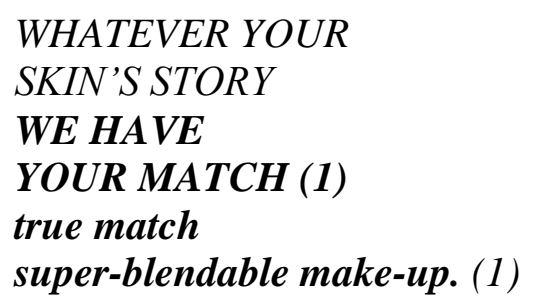

In her novel O'Neill shows freida's continuous efforts to match the beauty standard (there are special devices that determine clothing styles, make-up, medical prescriptions, etc.). Moreover, "eves" seek to be matched with "Inheritants". The very idea of a match, just as in the make-up adverts, is a fundamental blueprint.

The ideal of moral perfection is maintained through the "superego" (Freud 2018) and impositions construed by the dystopian universe. Freida blindly follows these impositions but her "id" starts to interfere. She is confronted with a sense of guilt when she does not repress her own impulses, such as her desire to stop taking pills, displays of affection towards Isabel, or giving in to her sexual desire for Darwin. Over the course of the novel, she begins to suspect that there is something inherently wrong with the system that governs her society: she does not even feel in possession of her own body or mind (a result of taking medical pills prescribed to every "eve" to prevent them from questioning their world). Her "ego", an identity she tries to project in the real world, is starting to crumble, and she rebels against her own fevered subconscious and the expectations of the system, for which she has become a burden. The "superego" does not represent or save the "id" but is in direct opposition to it, and the "ego" eventually "gives itself up because it feels itself hated and persecuted by the super-ego", in the analysis of Freud (55). Thus far she has had to constrain her desire to explore her sexuality (her lesbian affection for isabel), her actual desires (the urge to eat or stop taking pills). The system ruthlessly denies an eve the possibility of identifying her true self in any form:

Chastity magdalena is staring at my reflection in the wall, just another image of myself, one more image out of thousands and thousands that I've been presented with during my life, told this image is real, no, this one and this one and this one. I'm constantly trying to match all the thoughts in my head with these images in front of me, trying to put all the pieces of myself back together until I'm complete, until I can feel whole. (144) 
Likewise, in the mainstream magazine world, models are expected to abstain from eating and lesbian couples are never portrayed. While post-feminist theories foreground female multiplicity and the plurality of identities, media discourses undermine these notions and do not allow liminality. This multiplicity is not possible for freida, hence her inability to assemble all her pieces. In contrast to many twenty-first-century young adult dystopias that set out to subvert the "heteronormative ideals" (Day, Green-Barteet, and Montz 4) and the standards of the oppressive apparatus, O'Neill unravels a gloomy picture of woman's disintegration as a result of her failing to transcend the confines of this world. She is caught up and torn between schema which she intuitively deems pernicious but is unable to subvert. The unopposed naturalization of this world order hyperbolizes our modern society which has embraced the imagery of the "glossies" as part of our daily lives and townscape. Their nonalternative discourse seems to have reached a stage where it "may come to be seen as simply 'there' in a common-sense way, rather than socially put there" (Fairclough, "Introduction" 9).

\section{The female body}

O'Neill shows that a female body remains a "contested and contestable space" (Day 79), as the eves are being compelled to follow instructions on how to manage their bodies. The main postulate is "fat girls should be made obsolete" (119). The beauty industry, indeed, refuses to embrace different body shapes by "othering' them, that is, pushing them into the margins of beauty discourse. This is why freida considers her thinness a "comforter". For isabel, on the contrary, the body becomes a symbol of resistance when she attempts to reclaim it by eating more and letting herself put on weight. Such actions immediately lead to trouble, as she is quickly punished by the school's authorities. Nonetheless, it is notable that it is her body, her physical cage, that becomes an instrument of struggle.

One of the CDA's concerns with advertising featuring female bodies is that they are becoming clone-like, android entities with zero measurement errors. The adverts in Cosmopolitan hyperbolically affirm: "Refines and perfects skin. Even at pixel-level" (81). The percentage of spots, fine lines, and pores that need to be eradicated, corrected, improved (these synonyms and repetitions recur in the discourse itself) are precisely quantified. Similarly, freida states that "a complete re-design would be nice" (12), which parallels the magazine's assumption about women's skin being a computer image that can be given any desired reconfiguration "at pixel-level". On a side note, freida uses a striking number of repetitions and very similar structures in her own discourse throughout the novel (a recurrent strategy for conveying the message in advertising). O'Neill thereby succeeds in visualizing the self-neglecting side of a woman taken advantage of by a public discourse imbued with the subversion of values: the natural is unnatural and unwelcome, and the unnatural is natural. The eves' school seminars echo the advertising discourse: "Please note the lack of symmetry in the face, the bulbous noses, the dilated pores over the forehead and chin. Undesigned, natural women" (59). In both discourses, a woman is asked to engage in the process of selfimprovement as if she were a model on a factory assembly line: "As you know, girls, there is always room for Improvement. With every year since your design date, you are getting older, losing your bloom, depreciating in value. Standards, girls! Standards must be upheld" (58). These girls are treated as goods whose quality is to be observed at all times.

The above concepts only strengthen the hidden implication that the female body is a commodity, that is, on the one hand, a product of individual and collective labour and, on the other, has value only through social relationships. This Marxian idea of commodity applies to both discourses, in which women's bodies are being sold like any other product or are a means to an end in pleasing the "customer" - an "Inheritant". 
In Only Ever Yours the female body does not even seem to belong to the private sphere of woman's self, but is the property of the Father or the Inheritant. The latter attribute a certain fetishism to women's bodies which they want to possess to satisfy their social needs (observation of the social order and child-bearing). In Marx's expression, a commodity is a "mysterious thing" (83) by virtue of its interaction with fluid social trends and attitudes. These help establish use-value relationships between societal members, making them mutually necessary for each other. A body-commodity may be easily manipulated as it shows no resistance, it is "docile". Foucault provides a critique of manipulable bodies: "A body is docile that may be subjected, used, transformed and improved" (136) in military, economic, and political discourse. In a similar manner, a female body is appropriated and used to exert control over women: they shall comply with the dominant expectations before they can enter the sociocultural realm, if ever.

In fact, there are two body schemes: the body as a means of subjugation and, paradoxically, a source of power. Freida repeats that if she makes a proper use of her body and attracts Darwin, the highest-ranked Inheritant, she can finally gain some power after her otherwise powerless and secluded existence in the training school. Her fetishized body can help her get out if she succeeds in "selling" it (to compare, the languages of animalization "cat eye" - and dehumanization - "doll eye", are typical rhetorical devices in ads that give clues about how to reinforce one's charms and attract undivided attention). The body is also the only mechanism of self-realization known to "concubines", the epitome of the "fallen woman". Their exaggerated sexuality, however, is "othered" by the rest of the eves.

The advertising discourse also relocates the supposedly feminist discourse into its realm: a highly expressed sexuality becomes a means of proclaiming an emancipated self and freedom: "Or how powerful it can make you feel" (104) (about the "classic chic" look), "I want to show off my new confidence." "I want to show off my new ass.", "Get what you really want. Slim - fast!" (137). There are even syntactic parallelisms, that is, direct correlations between physical body parts and psychological states when advertisers "link the normative practice of beautification with an emancipated identity" (Lazar 37). In this false feminism, women are to internalize their objectification as a matter of choice and even an expression of power. While McRobbie praised some scarce examples from magazines that managed to demonstrate "self-confidence and openness to the world rather than a retreat from it" (191) in the otherwise narrow-minded world of "commercial femininity", the aforementioned more contemporary examples look like satirical surrogates of the aforementioned self-confidence and openness. Gough-Yates criticizes such pretences on part of the glossies "constituent in the fabrication of 'a post-feminist' emancipation" (38), as exemplified by the Cosmopolitan cover.

The female body also becomes the ultimate trap if a woman deviates from the expected behaviour, as seen in freida's victimization and scatological downfall (urination in a locked room after having violated the school rules of interaction with men). Ironically, her body, her only "comforter" in her struggle to survive in her world, becomes her worst enemy. The scatological element in writing the body, crucial for feminist criticism, is essential to understand the degree to which the woman's body and psyche are appropriated. To go even further with her criticism, in the last scene of the novel, O'Neill alludes to freida's body being summarily disposed of by one of the school's engineers. Her downfall is tied to her inability to accept or even fully understand what it means to be a young woman, a feat ironically rendered impossible due to "the manipulation of the female body, the biased utilisation of science and technology or the woman's lack of intervention in the decision-making process" (Elices 95). 


\section{As for men}

Chaos and hysteria - qualities typically attributed to females throughout the centuries - are exactly the characteristics that are forbidden in "eves". Just as the first woman was made for Adam in the Biblical story, these girls are created to calmly submit to the norm and to fulfil men's needs. To maintain this, women are constantly reminded of the male presence in the outer world. These ideas equally refer to both discourses.

Yet another advert's imperative, "Find your prints charming" (10), reveals a fascinating phonetic word play (compare Prince Charming and prints charming) that presupposes a woman's search for her prince charming. The idea is expressed in the visual image of her sitting on a man's lap dressed in "prints". The prints' design, resembling leopard's skin, immediately invokes the animalistic view of a woman who is to be tamed and then entrusted into a man's protection. It must be observed that O'Neill is unequivocally aware of this animalization device and incorporates it into her story: "With her leopard-print leotard and pleather shorts, she looks dangerously sexy" (211). Such awareness makes her rhetoric especially credible and up-to-date.

The question remains as to what powers are responsible for nurturing rigid prototypes with the help of abundant advertising discourse tropes. The dystopian impulse that rules Only Ever Yours demonstrates this in the best traditions of the genre. There is the omnipresent totalitarian figure of the Father, who maintains the sociocultural and political marginalization of women. It is evident that this serves as a metaphor for the state of affairs in the magazine industry too. O'Neill's world is engulfed with stereotyped notions prescribed by an allknowing, God-like narrator, as in pre-modernist novels. In reality, these notions are the result of many minds and are in no way able to address the needs of a typical woman, since the very idea of a "typical woman" is dubious and even offensive. The attempt to generalize female experience only contributes to disregarding the uniqueness of each female voice and makes it possible to impose certain societal demands on their life choices. It is a technique frequently exercised in totalitarian societies to undermine and suppress individuality in all its forms. Does it not remind the reader of the totalitarian-like atmosphere perpetuated by the beauty industry?

Technological manipulation in O'Neill's novel also subverts the very idea of a technologically advanced, postmodern society. The dystopian world puts science at its service, promoting only the advances directly related to maintaining obedience and conformity (e.g. medicines promising to avoid fatigue or ensure the sleeping regime). These look like a cruel parody of advertising messages that require women to believe in the scientific authenticity of "miraculous" products.

\section{How many "-isms"?}

Cosmopolitan's stance leaves the impression that all women should fit the same design, which recalls another extreme case of commodification: interchangeable Soviet bodies perfectly suited to the needs of the regime. Soviet sports advertising posters, for example, came to represent the perfect bodies of the revolution and used the cult of physical education for the purposes of the communist state: "Physical culture was in no sense to be understood as hedonistic appreciation of the body for its own sake. Instead, fitness was a means of making the individual citizen a functional and obedient instrument of the new state" (Kelly 268). While the magazine's discourse seems to make a case for hedonistic appreciation, it is more likely appropriating from it and exhibiting images convenient for the market and "male gaze" ideology. This leads to "women" in the plural, a problematic term within the postmodern feminist conversation: it is difficult to avoid stereotyping and to find individuality in any of 
these models. In the foundation shades' advert (Cosmopolitan 1) three different, yet completely interchangeable, women invite the female consumer to become one of them: Aimee, Liya, or Jennifer. Hollywood actresses Aimee Mullins, Liya Kabede, and Jennifer Lopez are referred to by their first names, which in itself is a typical recurrent device in sexist discourse, and wear the same make-up that completely annihilates their unique features. Glancing at this flashy ad, one may recall freida's words:

I sometimes think the modifications have left liu's features almost bland, so diluted that they are almost interchangeable with mine, or megan's, or naomi's. All that is different is our skin tone and hair colour. But at least we still have some diversity, however marginal. It's rumoured that nowadays only blonde, blue-eyed girls are designed in the Afrika and Chindia Zones, their past literally whitewashed. (58)

Additionally, in using lower-case letters for the characters' names, reminiscent of the firstname address in the ads, O'Neill minimizes their significance and individuality within her dystopian setting. Lost behind the rows of diminished first names, her characters unconsciously parody the many similar images of women boldly appropriated by beauty discourse. In yet another advert there are simply three unnamed similarly dressed models presumably representing three sides of womankind in syntactically parallel constructions: "She's sporty. She's sexy. She's glam" (22-23). In all, terms like feminism, hedonism, and pluralism lose all their original meaning in the dystopian setting of the beauty genre, which makes women the victims of the "Father's" philosophy which has an interest in maintaining the "eves" assembly line.

Beyond its sexist approach to the female body, media discourse has long been known for "othering" and under-representing different ethnicities. As exemplified by the above citation, to satirize even further the quest to de-individualize women, O'Neill's dystopia dives into the complex issue of race, thereby reiterating the world scheme of an under-represented ethnic diversity of women. It is noteworthy that the first African-American woman appeared on the cover of Vogue only in 2014. In this respect, it also seems important to recall the experiment ${ }^{5}$ conducted by American sociologists Kenneth and Mamie Clark in 1939-1940, wherein little girls were asked to pick a doll that looked good or pretty to them. The experiment showed that the black doll was most underappreciated and neglected, even by African-American kids. Even though many years have passed, the experiment and social profiling still indicate a serious bias. To show that this bias still has a hold over people in the twenty-first century, O'Neill offers a scene in which "eves" continue to favour light-skinned models on social networks. What is curious is that the beauty adverts analysed for the present article only rarely portrayed models of non-white origins, and even if they did, they always explicitly commented on it (e.g. "57 ethnic backgrounds" (2), "proven effective for every ethnicity" (6)), seeming thus to use a socially poignant discourse as a marketing move, commercializing diversity but failing to subvert racism.

Furthermore, there seems to be a linguistic and paralinguistic marginalization of elder people, who are never positively marked. It is implied by the advert's visual image (Cosmopolitan 118-119) that children will only accept and love their mothers or grandmothers if they undergo procedures of perfection. As a demonstration of ageism pervading beauty discourse, the term "ageing" is presented from a negative perspective, since "miracle skin perfector" is required to deal with it, providing an anti-ageing alternative. A more positive visual counterpart is at hand, and the child kisses the more appropriate version of her parent or grandparent. O'Neill manages to foreground this issue by offering scenes in which aged women subject their bodies to surgery in order to stop them deteriorating and to enable them to continue to attract interest from men. Through making the same lexical choice 
as the adverts, O'Neill seems to channel the actual language schemes of advertising: "younger eves coming up after us, with their fresher skin and their brighter eyes" (29) (comparatives, binary oppositions, "us" vs "them"). Or, on reading "You look so tired in your photo. I can lend you some of my new concealer if you'd like. It's supposed to work miracles", the entire semantic field of adverts comes to mind with its concealers and their miracles. Qualities other than beauty, freshness, and youth are to be disguised - an implication targeted by O’Neill.

\section{Conclusions: Is there a Place for Feminism?}

Rigorous social critic Naomi Wolf has pointed out that with the emergence and proliferation of market economies, beauty became an asset of capitalism. She continues to argue in her work that the beauty myth is an ideology that remains very strong in comparison with other questioned myths of domesticity, passivity, and motherhood, which have receded to a certain extent due to "second wave" and "third wave" feminism. While I do not share her optimism in respect to other myths, I hold that the discourse of the "glossies" continues to undertake consistent implicit, ideological work undermining woman's integrity: "By using ideas about 'beauty,' it ... reconstructed an alternative female world with its own laws, economy, religion, sexuality, education, and culture, each element as repressive as any that hone before" (Wolf 16). By "stocking" a woman with self-deprecation and anxiety, a huge sector of the beauty economy is kept afloat. Where are the actual women in this discourse: the engineers, programme designers, writers, teachers, mechanics, social workers? Looking at such magazines, one cannot but wonder whether they try to hypnotize the reader: "Pink's my favourite colour. Math is hard. Wanna go shopping?" (O’Neill 55, 56).

The detrimental effects of idealized and unrealistic advertising on young women and adolescents have been shown by research - "Body image for females was significantly more negative after viewing thin media images" (Groesz et al. 11) - and internalization of the latter renders them vulnerable to future negative effects of exposure (Halliwell 513). Rubino et al. further note that viewing oneself from an observer's perspective is even more hazardous, as "self-objectification can cause feelings of depression, shame, and anxiety" (168). While the present article has not discussed the actual effects of beauty magazine discourse (further research should be conducted on this matter), it has openly engaged with the potential risks of its discursive power threats for contemporary society. Similarly to CDA researchers, O'Neill's novel undertakes a critical study of social schemes, while deploying the creative frames of the dystopian genre.

One significant difference in the discursive tone of a beauty magazine and a dystopian novel is tonality. Whilst the former has an ecstatic atmosphere inspired by the sermon of an ultimate promise of a better life and glorification, the latter is conceived with no promise, apart from that of an inevitable nightmare. O'Neill debunks the mythical and utopian world of the beauty industry discourse and presents its dystopian side. She seems to share Baudrillard's view that such "simulacra ... have no referent or ground in any "reality' except their own" (5, 6). If, however, they happen to have a referent, it is not a "Disneyland" world. O'Neill's dystopia shows the consequences of schematizing and internalizing societal attitudes by virtue of which "you feminist" (O’Neill 84) becomes an insult.

Hopefully, feminist dystopias of the future will propose other scenarios in which ideological blocks are overcome and the familiar schemes are subverted by empowered heroines. 


\section{Notes}

${ }^{1}$ See https://www.hearst.com/magazines/cosmopolitan

2 Louisa Mellor, "Louise O'Neill interview: Only Ever Yours", Den of Deek, 12 May 2015, www.denofgeek.com/books-comics/only-ever-yours/35339/louise-o-neill-interview-only-ever-yours

${ }^{3}$ Cosmopolitan USA, September 2013. Ed. Coles Joanna.

${ }^{4}$ See https://www.instagram.com/nina/?hl=ru

${ }^{5}$ See Dixon Fuller 2011, "Doll Test", Youtube, 7 February 2012, www.youtube.com/watch?v=tkpUyB2xgTM

\section{Works Cited}

Althusser, Louis. On the Reproduction of Capitalism: Ideology and Ideological State Apparatuses. London and New York: Verso, 2014.

Ballaster, Ros, Margaret Beetham, Elisabeth Frazer, and Sandra Hebron. Women's Worlds: Ideology, Femininity, and the Woman' Magazine. London: MacMillan, 1991.

Bartky, Sandra. Femininity and Domination: Studies in the Phenomenology of Oppression. New York: Routledge, 1990.

Bartlett, Frederic Charles. Remembering: A Study in Experimental and Social Psychology. Cambridge: Cambridge University Press, 1995.

Bateman, John. Text and Image: A Critical Introduction to the Visual/Verbal Divide. New York: Routledge, 2014.

Baudrillard, Jean. Jean Baudrillard: Selected Writings. Ed. Poster Mark. Stanford: Stanford University Press, 1988.

Booker, Keith. The Dystopian Impulse in Modern Literature: Fiction as Social Criticism. Westport and London: Greenwood, 1994.

Bortolussi, Marisa and Peter Dixon. Psychonarratology: Foundations for the Empirical Study of Literary Response. Cambridge: Cambridge University Press, 2003.

Caldas-Coulthard, Carmen Rosa. "Women who pay for sex. And enjoy it': Transgression Versus Morality in Women's Magazines". Texts and Practices: Readings in Critical Discourse Analysis. Eds. Carmen Rosa Caldas-Coulthard and Malcolm Coulthard. London and New York: Routledge, 1996. 250-295.

Cook, Guy. A Theory of Discourse Deviation: The Application of Schema Theory to the Analysis of Literary Discourse. PhD thesis. University of Leeds, 1990. http://etheses.whiterose.ac.uk/12996/1/Cook\%2CGWD_English_PhD_1990.pdf . Discourse and Literature. Oxford: Oxford University Press, 1994.

Day, Sarah. K. "Docile Bodies, Dangerous Bodies, Sexual Awakening and Social Resistance in Young Adult Dystopian Novels". Female Rebellion in Young Adult Dystopian Fiction. Eds. Sarah Day, Miranda A. Green-Barteet, and Amy L. Montz. London and New York: Routledge, 2014. 75-95.

—, Miranda A. Green-Barteet, and Amy L. Montz. "Introduction: From 'New Woman' to 'Future Girl': The Roots and the Rise on the Female Protagonist in Contemporary Young Adult Dystopias". Female Rebellion in Young Adult Dystopian Fiction. Eds. Sarah K. Day, Miranda A. Green-Barteet, and Amy L. Montz. London and New York: Routledge, 2014. 1-15.

Elices, Juan F. "Othering Women in Contemporary Irish Dystopia: The Case of Louise O’Neill's Only Ever Yours". Nordic Irish Studies 15.1 (2016): 77-95.

Fairclough, Norman. Critical Discourse Analysis: The Critical Study of Language. New York: Routledge, 2013. 
. "Introduction". Critical Language Awareness. Ed. Norman Fairclough. London and New York: Routledge. 2013. 1-31.

Foucault, Michel. Discipline and Punish: The Birth of the Prison. New York: Random House, 1995.

Fredrickson, Barbara L. and Tomi-Ann Roberts. "Objectification Theory: Towards Understanding Women's Lived Experiences and Mental Health Risks". Psychology of Women Quarterly 21 (1997): 173-206.

Freud, Sigmund. The Ego and the Id. Mineola and New York: Dover Publications Inc, 2018.

Gee, James Paul. Social Linguistics and Literacies: Ideology in Discourses, Critical Perspectives on Literacy and Education. London and New York: Routledge, 1990.

Gough-Yates, Anna. Understanding Women's Magazines: Publishing, Markets and Readership. London and New York: Routledge. 2003.

Groesz, Lisa, Sarah Murnen, Michael Levine. "The Effect of Experimental Presentation of Thin Media Images on Body Satisfaction: A Meta-analytic Review". International Journal of Eating Disorders 31.1 (2002): 1-16.

Halliwell, Emma. "The Impact of Thin Idealized Media Images on Body Satisfaction: Does Body Appreciation Protect Women from Negative Effects?" Body Image 10 (2013): 509-514.

Hutcheon, Linda. A Poetics of Postmodernism: History, Theory, Fiction. London and New York: Routledge, 1988.

Ikaria-Maina, Nancy. "Discourse of Advertising: Reference to Kiswahili and English Adverts in Kenyan Media". International Journal of Science and Research 3.11 (2012): 15621568.

Kelly, Katriona. Refining Russia: Advice Literature, Polite Culture, and Gneder from Catherine to Eltsin. Oxford: Oxford University Press, 2001.

Lazar, Michelle. "The Right to Be Beautiful: Post-Feminist Identity and Consumer Beauty Advertising". New Femininities: Postfeminism, Neoliberalism and Subjectivity. Eds. Rosalind Gill and Cristina Scharff. New York: Palgrave Macmillan, 2011. 37-52.

Marx, Karl and Frederick Engels. Collected Works: Capital. Volume 1. New York: International Publishers, 1996.

McCracken, Ellen. Decoding Women's Magazines: From Mademoiselle to Ms. Macmillan. London: Palgrave Macmillan, 1993.

McRobbie, Angela. Back to Reality? Social Experience and Cultural Studies. Manchester and New York: Manchester University Press, 1997.

Menz, Florian. "Manipulation Strategies in Newspapers: A Program for Critical Linguistics". Language, Power and Ideology: Studies in Political Discourse. Ed. Ruth Wodak. Amsterdam and Philadelphia: John Benjamins Publishing Company. 1989. 207-249.

Miner-Rubino, Cathi Jean M. Twenge, Barbara L. Fredrickson. "Trait Self-objectification in Women: Affective and Personality Correlates". Journal of Research in Personality 36 (2002): 147-172.

O’Neill, Louise. Only Ever Yours. London: Quercus, 2014.

Plottel, Jeanine Parisier. "Introduction". Intertextuality: New Perspectives in Criticism. Eds. Jeanine Parisier Plottel and Hanna Charney. New York: New York Literary Forum, 1978.

Reah, Deborah. The Language of Newspapers. London and New York: Routledge, 1998.

Semino, Elena. "Schema Theory and the Analysis of Text Worlds in Poetry". Language and Literature 4.2 (1995): 79-108.

Stockwell, Peter. Cognitive Poetics: An Introduction. London and New York: Routledge, 2002. 
van Dijk, Teon A. Handbook of Discourse Analysis. London, Austin, Tokyo: Academic Press, 1985.

van Dijk, Teon A. "Introduction: The Common Roots of the Studies of Literature and Discourse". Discourse and Literature: New Approaches to the Analysis of Literary Genres. Ed. Teon A. van Dijk. Amsterdam and Philadelphia: John Benjamins Publishing Company, 1985. 1-11.

van Dijk, Teon A. "Discourse Semantics and Ideology in Discourse and Society". Discourse and Society 6.2 (1995): 243-289.

Vukadinovic, Jelena. Role of Women in Utopian and Dystopian Novels. Norderschtedt: GRIN Verlag, 2009.

Widdowson, H.G. Text, Context, Pretext: Critical Issues in Discourse Analysis. Malden: Blackwell Publishing, 2004.

Wilson, Sharon R. Women's Utopian and Dystopian Fiction. Cambridge: Cambridge Scholars Publishing, 2013.

Wodak, Ruth and Meyer Michael. Methods of Critical Discourse Analysis. Los Angeles, London, New Delhi, Singapore, Washington DC: SAGE, 2009.

Wolf, Naomi. The Beauty Myth. New York: Harper Collins, 1991.

Wynne, Deborah. The Sensation Novel and the Victorian Family Magazine. New York: Palgrave, 2001.

Received: 23 August 2017

Revised version accepted: 23 December 2017

Ekaterina Muraveva is a Ph.D research student under the supervision of Dr. Juan Francisco Elices Agudo at the University of Alcalá, Spain. She has also taught English language courses at the Polytechnic University of Peter the Great in Saint-Petersburg, Russia. Her area of interest includes English and Russian Dystopian Literature, Gender Studies and Discourse Analysis.

eka.mur1989@gmail.com 